\title{
Comparison of in vivo antibacterial and antithrombotic activities of two types of pulmonary artery catheters in pig
}

Jung Wook Han ${ }^{1,2}$, Yeon Soo Shin'², Jung Ju Kim² and Ho Sung Son ${ }^{1,2^{*}}$

\begin{abstract}
Background: During pulmonary artery catheter (PAC) implantation, inaccurate measurements of hemodynamic parameters due to infection or thrombosis of PAC can result in severe complications.

Method: In order to develop a new PAC material, we evaluated the antibacterial and antithrombotic activities of the two types of PAC (Swan Ganz catheter and prototype catheter) in 14 pigs.

Results: In the 3-day group, bacterial infection rate was not different between the two types of PAC. In the 7-day group, bacterial infection rate of the prototype catheter was twice as elevated as that of the Swan-Ganz catheter. In the 3-day group, thrombus formation rate of the prototype catheter was twice as elevated as that of the Swan-Ganz catheter. In the 7-day group, thrombus formation rate was the same for the two types of PAC.
\end{abstract}

Conclusion: Here, we report an experimental pig model that confirms differences in antibacterial and antithrombotic activities.

Keywords: Pulmonary artery catheter, Infection, Thrombosis, Pig

\section{Background}

Pulmonary artery catheter (PAC) has been widely used in critical care since the 1970s. It is reported that 1.5 million PACs are used annually in the United States to monitor hemodynamic status of critically ill patients [1]. It plays an important role in assessing the patient's condition in the intensive care unit or operating room, establishing a diagnosis of underlying pathology and deciding on the treatment plan by measuring hemodynamic parameters, such as cardiac output, mixed venous oxygen saturation and intracardiac pressures [2-6].

PAC consists of blood compatible catheter, temperature sensor and monitoring system. Biofilm formation due to infection or thrombosis near temperature sensor has been reported to cause serious problems [7-9]. As a result, the sensitivity of sensor was also reduced [10]. Currently, most cardiovascular medical devices are coated with lubricant, antithrombotic or antimicrobial agents. But there are no products that fundamentally solved serious side effects caused by prolonged implantation.

We compared the antibacterial and antithrombotic activities of the most commonly used PAC, Swan-Ganz catheter (CCCO Combo catheter: Vigilance II, Edwards ${ }^{\circ}$ Lifesciences, California, USA), with those of the prototype catheter in a pig model in an effort to develop a new catheter material.

\footnotetext{
* Correspondence: hssonmd@korea.ac.kr

${ }^{1}$ Department of Thoracic and Cardiovascular Surgery, Korea University

Medical Center, \#73, Inchon-Ro, Sungbuk-Gu, Seoul 136-705, South Korea

${ }^{2}$ Korea Artificial Organ Center, Korea University, \#73, Inchon-Ro, Sungbuk-Gu,

Seoul 136-705, South Korea
} 


\section{Materials and methods}

Main difference between the two types of PAC is antithrombogenecity. Prototype catheter improved antithrombotic activity through a newly developed heparin coating procedure. Prototype catheter was composed of $72 \%$ Pellethane ${ }^{\bullet} 2363-55 D$ (CAS \# 37383-28-1, Compounding Solutions, Lewiston, Maine, USA), 20\% Barium Sulfate (CAS \# 7727-43-7, Compounding Solutions, Lewiston, Maine, USA) and 6\% AD85H-M ${ }^{\odot}$ (Antimicrobial agent, Compounding Solutions, Lewiston, Maine, USA). The shape of prototype catheter was similar to that of Swan-Ganz catheter.

Because several studies have documented that the cardiovascular system in pig is similar to that in humans, when compared with other animal models [11-13], we experimented with 14 female pigs. The subjects of this study were female Yorkshire Swine pigs weighing $45 \pm 5 \mathrm{~kg}$. The animals used in our experiments came from farms (XP bio ${ }^{\oplus}$ or Optipharm $^{\circ}$, Cheongju, Korea) licensed by the Ministry of Food and Drug Safety, Republic of Korea. Pigs were moved from this farm to the Laboratory Animal Research Center Korea University College of Medicine 7 days before experiment and were housed in individual cages under controlled environments until experiment.

Bilateral external jugular veins were used to reduce errors due to individual difference (Fig. 1a). Experiments were conducted as follows. Prophylactic antibiotics (cefazolin 1 g, Chong Kun Dang ${ }^{\oplus,}$ Seoul, Korea) were injected intravenously $1 \mathrm{~h}$ before skin incision. General endotracheal anesthesia was induced with thiopental sodium 5-10 $\mathrm{mg} / \mathrm{kg}$ and vecuronium bromide $0.1 \mathrm{mg} / \mathrm{kg}$. Bilateral external jugular veins were exposed under sterile condition. Before jugular vein clamping, unfractionated heparin $50 \mathrm{IU} / \mathrm{kg}$ was injected intravenously. The fragment of catheter cut into $3 \mathrm{~cm}$ length was inserted into the vein via a tiny
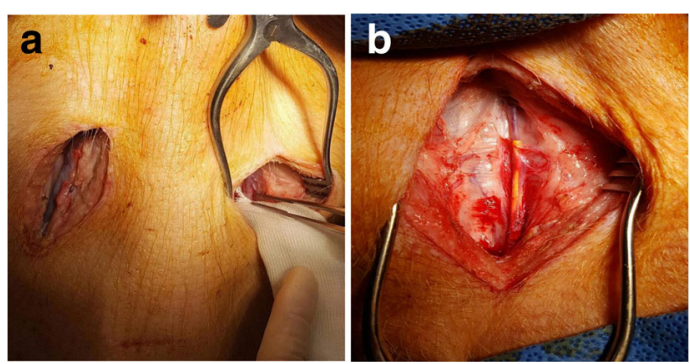

Fig. 1 Operative findings. a Exposure of both external jugular veins, b External jugular vein containing a catheter fragment slit and were held to the vein with 6-0 prolene suture, which was used to close the venotomy (Fig. 1b). After hemostasis, the surgical wound was closed layer by layer. Low molecular weight heparin (LMWH, Clexane, Sanofi-Aventis ${ }^{\oplus}$, Paris, France) at a dose of 1 $\mathrm{mg} / \mathrm{kg}$ was injected subcutaneously every day until the catheters were removed. Three days later, 7 pigs underwent reoperation to remove the catheters. External jugular vein containing the catheter was resected into $4 \mathrm{~cm}$ length. We were careful not to disturb any thrombus that may have been present. The remaining 7 pigs underwent reoperation 7 days later. At the end of the operation, all pigs were euthanized by intravenous injection of potassium chloride $2 \mathrm{mEq} / \mathrm{kg}$.

\section{Results and discussion}

Catheter tip culture was performed, and the culture was subsequently incubated for $48 \mathrm{~h}$ to evaluate antibacterial activity. The results are listed in Table 1 . In the 3-day group, the bacterial infection rate was not different between the two types of PAC (42.86\%). In the 7-day group, the bacterial infection rate of the prototype catheter (57.14\%) was twice as elevated as that of the Swan-Ganz catheter (28.57\%). Early in the experiment, the bacterial infection rate was as high as in the two types of PAC. The cultured bacteria were mainly normal flora in the gastrointestinal tract or the skin [14-16]. Therefore, contamination was suspected. After more carefully attending to sterilization and dressing, the bacterial infection rate decreased towards the end of the experiment.

Catheters implanted in pigs were isolated and examined under a microscope to determine the presence of thrombus.

The weight of thrombus was measured to evaluate antithrombotic activity from the 4th experiment. The results are listed in Table 2 . In the 3-day group, the thrombus formation rate of the prototype catheter (85.71\%) was twice as elevated as that of the Swan-Ganz catheter $(42.85 \%)$. In the 7 -day group, the thrombus formation rate was not different between the two types of PAC (71.43\%). In the 3-day group, the mean thrombus amount of the prototype catheter $(0.12 \mathrm{~g})$ was six times as elevated as that of the Swan-Ganz catheter $(0.02 \mathrm{~g})$. In the 7 -day group, the mean thrombus amount was $0.07 \mathrm{~g}$ in the prototype catheter and $0.12 \mathrm{~g}$ in the Swan-Ganz catheter. Despite anticoagulation therapy with LMWH, an increase in vulnerability to thrombus formation was observed in the PAC group, regardless of the type.

\section{Conclusion}

In conclusion, after the 7-day implantation, there were differences in the rate of infection and thrombus 


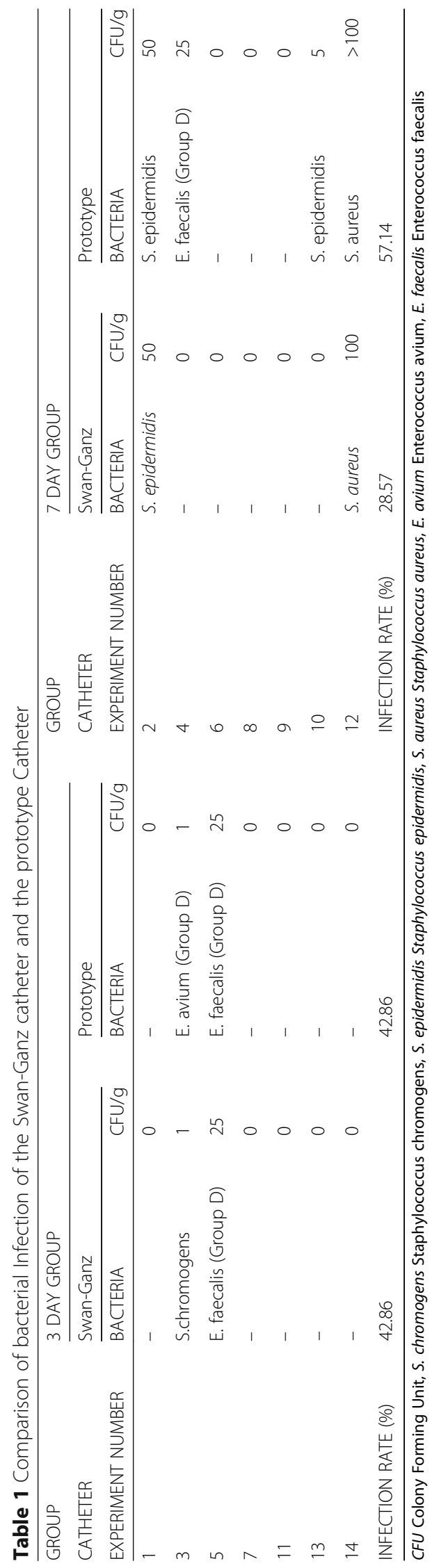




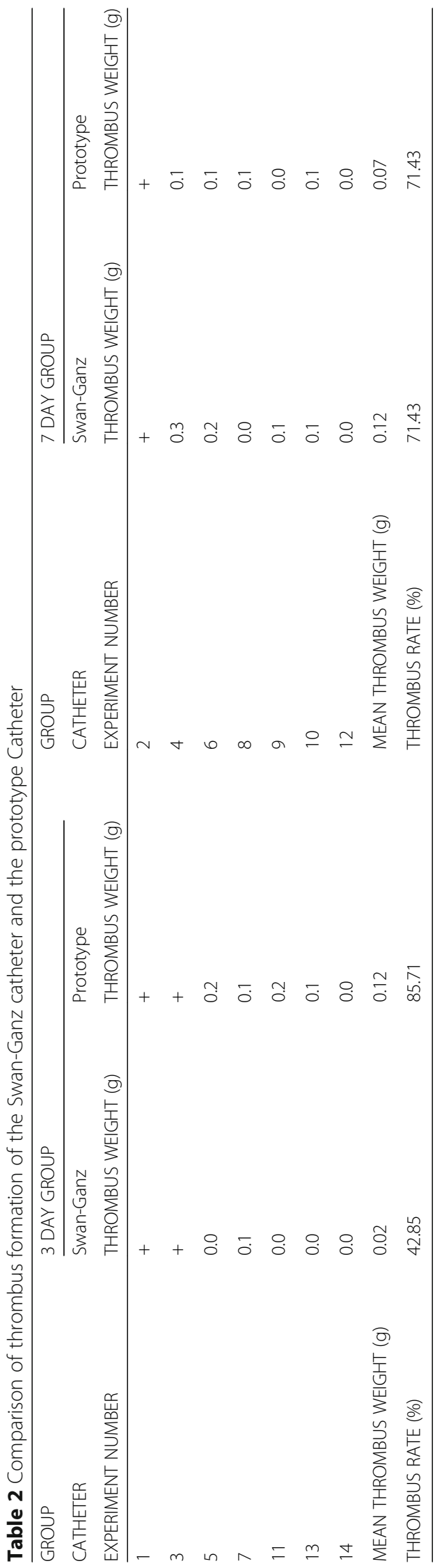


formation between the Swan-Ganz catheter and the prototype catheter. The differences in these outcomes based on the material of the catheter.

\section{Abbreviations}

CFU: Colony forming unit; E. avium: Enterococcus avium; E. faecalis: Enterococcus faecalis; LMWH: Low molecular weight heparin; PAC: Pulmonary artery catheter; S. aureus: Staphylococcus aureus; S. chromogens: Staphylococcus chromogens; S. epidermidis: Staphylococcus epidermidis

\section{Acknowledgements}

Not applicable

\section{Funding}

This research was supported by the Bio \& Medical Technology Development Program of the National Research Foundation (NRF) \& funded by the Korean government (MSIP \& MOHW) (2015M3A9E2028644).

\section{Availability of data and materials}

All data generated or analyzed during this study are included in this published article.

\section{Authors' contributions}

JWH performed in vivo experiments and drafted the manuscript. YSS, JJK and $\mathrm{HHS}$ designed in vivo experiments and helped to draft the manuscript. All authors read and approved the final manuscript.

\section{Ethics approval}

The Korea University College of Medicine Institutional Animal Care and Use Committee (IRB No. korea-2016-0118) approved this experiment protocol.

\section{Consent for publication}

All authors consent for publication.

\section{Competing interests}

The authors declare that they have no competing interests.

\section{Publisher's Note}

Springer Nature remains neutral with regard to jurisdictional claims in published maps and institutional affiliations.

Received: 5 July 2017 Accepted: 19 October 2017

Published online: 15 November 2017

\section{References}

1. Bernard GR, Sopko G, Cerra F, Demling R, Edmunds H, Kaplan S, Kessler L, Masur H, Parsons P, Shure D, Webb C, Weidemann H, Weinmann G, William D. Pulmonary artery catherization and clinical outcomes. National Heart, lung and blood institute and Food and Drug Administration workshop report. JAMA. 2000;283:2568-72.

2. Swan HJ, Ganz W, Forrester J, Marcus H, Diamond G, Chonette D. Catheterization of the heart in man with use of a flow-directed balloontipped catheter. N Engl J Med. 1970;283:447-51.

3. Whitener S, Konoske R, Mark JB. Pulmonary artery catheter. Best Pract Res Clin Anaesthesiol. 2014;28:323-35.

4. Connors AF Jr, Speroff T, Dawson NV, Thomas C, Harrell FE Jr, Wagner D, Desbiens N, Goldman L, AW W, Califf RM, Fulkerson WJ Jr, Vidaillet H, Broste S, Bellamy P, Lynn J, Knaus WA. The effectiveness of right heart catheterization in the initial care of critically ill patients. JAMA. 1996;276:889-97.

5. Mimoz O, Rauss A, Rekik N, Brun-Buisson C, Lemaire F, Brochard L. Pulmonary artery catheterization in critically ill patients: a prospective analysis of outcome changes associated with catheter prompted-changes in therapy. Crit Care Med. 1994;22:573-9.

6. Nagy Al, Venkateshvaran A, Dash PK, Barooah B, Merkely B, Winter R, Manouras A. The pulmonary capillary wedge pressure accurately reflects both normal and elevated left atrial pressure. Am Heart J. 2014;167:876-83.

7. Myers ML, Austin TW, Sibbald WJ. Pulmonary artery catheter infections: a prospective study. Ann Surg. 1985;201:237-41.
8. Parotto $M$, Jariani $M$, Wijeysundera $D$, Meineri $M$. Early thrombus formation on a pulmonary artery catheter. Intensive Care Med. 2015:41:1831-2.

9. Dentz ME, Slaughter TF, Mark JB. Early thrombus formation on heparin bonded pulmonary artery catheters in patients receiving epsilon aminocaproic acid. Anesthesiol. 1995;82:583-6.

10. Rapoport J, Teres D, Steingrub J, Higgins T, McGee W, Lemeshow S. Patient characteristics and ICU organizational factors that influence frequency of pulmonary artery catheterization. JAMA. 2000;283:2559-67.

11. Wu J, Luo X, Huang Y, He Y, Li Z. Hemodynamics and right-ventricle functional characteristics of a swine carotid artery-jugular vein shunt model of pulmonary arterial hypertension: an 18-month experimental study. Exp Biol Med. 2015;240:1362-72.

12. Swindle MM, Makin A, Herron AJ, Clubb FJ Jr. Frazier FJ. Swine as models in biomedical research and toxicology testing. Vet Pathol. 2012;49:344-56.

13. Swindle MM, Smith AC, Hepburn BJ. Swine as models in experimental surgery. J Investig Surg. 1988;1:65-79.

14. Murray BE. The life and times of the Enterococcus. Clin Microbiol Rev. 1990;3:46-65.

15. Fey PD, Olson ME. Current concepts in biofilm formation of Staphylococcus Epidermidis. Future Microbiol. 2010:5:917-33.

16. Kluytmans J, van Belkum A, Verbrugh $H$. Nasal carriage of Staphylococcus Aureus: epidemiology, underlying mechanisms and associated risks. Clin Microbiol Rev. 1997;10:505-20.

\section{Submit your next manuscript to BioMed Central and we will help you at every step:}

- We accept pre-submission inquiries

- Our selector tool helps you to find the most relevant journal

- We provide round the clock customer support

- Convenient online submission

- Thorough peer review

- Inclusion in PubMed and all major indexing services

- Maximum visibility for your research

Submit your manuscript at www.biomedcentral.com/submit
) BioMed Central 